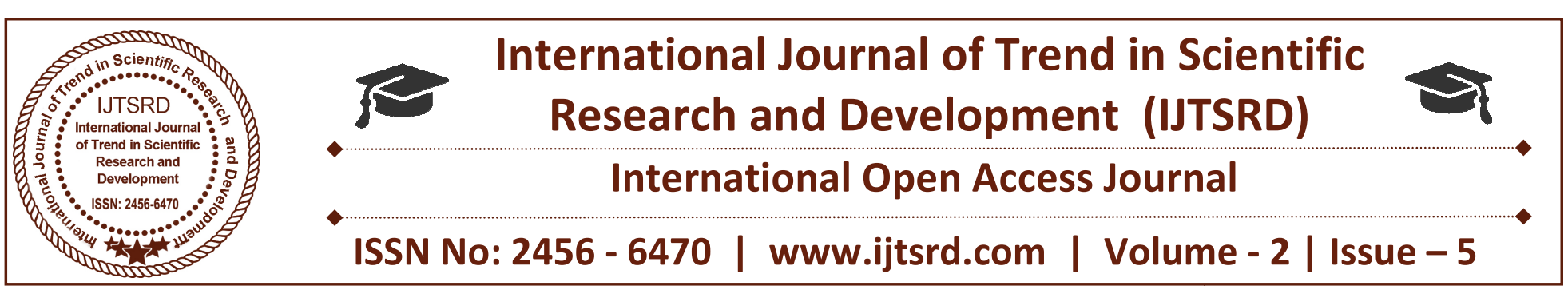

\title{
Analysis of the Agriculture and Industrial Segment
}

\author{
Satish Kumar Singh \\ B.A., L.L.B. (Hons) - II Sem., Indore Institute of Law, Affiliated To DAVV and BCI, \\ Indore, Madhya Pradesh, India
}

\begin{abstract}
In this research the researcher told about the farmers of the India and the position of the farmers in India, the agriculture sector in India. The position of the agriculture sector in 19th century and before the 19th century the position of the agriculture sector in India, How do the farmers do the agriculture before 19th centuries and now the farmers do the agriculture in India, after the Second World War? How the agriculture is helpful to the industrial sector. And also, the researcher told in his research about the industrial sector and how the industrial sector is useful to the agriculture sector. And his research the researcher also wand to told about the relation between agriculture sector, industrial sector and the service sector. The research told about the position of the industrial sector before the world war second in India and told about the position of the industrial sector after the Second World War. The researcher also told about the Industrial sector how to the work and how the GDP of our country increases, and how the industrial sector is useful for the development of the GDP of our country and what is the GDP of the nation.
\end{abstract}

\section{INTRODUCTION}

The agriculture industry is the most important component of the Indian economy it is giving his contribution to progress the GDP of the country as well as helps to progress the employment in the country. In this time this sector is showing the so much opportunity to the employers of the country. The agriculture sector is known as the farming industry in India. The farming industries are consisting of fruits vegetables, gains, plantation of the crops, pulses and the spices, these products are representing the largest sector of the Indian agriculture industry. All the farming industries are followed by the food processing industry, dairy industries and the fertilizer industry. India is presently third largest country in the field of agricultural producer. First country is UNITED STATE OF AMERICA, and the second country is CHINA. The Indian agriculture industry has grown at a CAGR of around $11.7 \%$ in last 5years. ${ }^{1}$ This sector is almost $18.5 \%$ giving his contribution for the development of the GDP of the country. According to this analyst the turnover of the total food market is 250000 crores per year. In year 1990-1991, the contribution of the agriculture to the country's GDP output was 32\% which was decreased to $20 \%$ in year $2005-2006$. The agricultural sector is come under the primary sector and the industrial sector is come under the secondary sector.

Industrial sector is manufacturing industry and construction. Secondary sector or the industrial sectors are make up the economy of the country. After the agricultural sector and industrial sector, one sector more which is known as the name of the service sector, And the hospitality, consulting and nursing are the come under the service sector. Industrial sector usually buys the raw materials from the agriculture sector and make the new products. The industrial sector or the secondary sector can be classified by the two types; first is that heavy industry and the second is that light industry. ${ }^{2}$

In industrial sector large quantities of the energy are consumed to the running process. The manufacturing

\footnotetext{
${ }^{1}$ http://www.indianmirror.com/indianindustries/agricultural.html, last visited at 14:44 dated on 14/07/2018

${ }^{2}$ https://www.imarcgroup.com/agriculture-industry-in-india, last visited at 14:50 dated on 14/07/2018
} 
industries are tending to generate the source of environmental problems.

The industrial sector is not the substitute of the agricultural sector. Both of them are the complementary to one another. Both of these sectors are so much attached with each other that is not possible of the development of the one sector without the improvement of the other sector. If agriculture sector is considered as the heart of the country, then the industry must be considered as the brain. The agriculture sector is regularly supply the raw material to the industrial sector like that sugarcane, jute, cotton, wheat, paddy etc. to the consumer goods industries. The farmers, households used to save the money in the bank and other financial institution which ultimately is used by the industry owners in the form of investment. ${ }^{3}$

\section{Development Of The Agriculture Sector In Our Country:}

India is the mainly agriculture county. The agriculture sector is affiliated with another sector. This is the largest livelihood provider sector in India. The maximum industrial sectors are depending upon the agriculture sector because this sector is provided the raw material to the agriculture sector. The industrial sector regularly investments in the technology development, irrigation infrastructure, to emphasis on modern agricultural practices and provisions of agricultural credit and subsidies are the major factors contributed to agriculture growth. In past two decades the Indian agriculture has undergone rapid transformation. The new policy of globalization and liberalization has opened up new avenues for agricultural modernization. In this time India is consistently producing 250milion tons of food grains. Near about 100 million tons of rice, 90 million of wheat, 35 million bales of cotton and more than 18 million tons of pulses. The growth is mainly facilitated by the Krishi Vigyan Kendra's (KVK). ${ }^{4}$ this system which is speared across the country. The prime Minister's Economic Advisory council (PMEAC) has recorded the fiscal growth of the agriculture sector is 4.8 percent in this year. The maximum people of the country they are participated in the field of agriculture. The agriculture minister said that India has emerged as a major player in the

\footnotetext{
${ }^{3}$ https://www.omicsonline.org/open-access/agriculture-role-onindian-economy-2151-6219-1000176.php?aid=62176, last visited at $15: 10$ dated on 14/07/2018 ${ }^{4}$ IBID
}

global agriculture market. In last five years the country's exports have also increases tripled from around 80000 crores to 2.32 trillion. The government of congress was launched the scheme of national food security mission form Rabi, 2007-2008. The main target of the fundamental of the national food security mission is to expand the production of rice, wheat, pulses, and coarse cereals through region extension and efficiency upgrade in a supportable way in the recognized locale of the nation; restoring soil ripeness and profitability at the individual ranch level; and improving farm level economy to restore confidence amongst the farmers. This mission is mainly focused to generate the extra rice, wheat, and the heartbeats. The training is the important factor for the improvement because it serves to recognize present issues and future difficulties. IFFCO has launched a mobile application and a web portal, which is known as the name of the IFFCO iMandi to address all needs of the farming community associated with it. ${ }^{5}$ The farmers are using this application and buy the agri inputs of IFFCO, including seeds, fertilizers, agro chemicals at discount price and get free delivery at their doorstep. IFFCO is large scale fertilizer cooperative federation in India which is registered as multistate cooperative society. It's headquartered in New Delhi. ${ }^{6}$ The Union ministry of agriculture has passed a act for the welfare of the Farmers to ensure better price to farmers. The aim of this act is that to reducing farmers risks by creating assured market for their produce at pre - agreed price and also encouraged them to investment from agribusiness and food processing industries by enhancing productivity. The producer of the goods can sell agricultural produce at specific price in future to buyer as per his previous agreement.

\section{Development Of The Industrial Sector In Our Country:}

Industrial sector is also known as the secondary sector. The development of the India a modern industrial country, this process is very slow but continuing process. India's first Prime Minister, Jawaharlal Nehru, saw that industrialization is the best option to remove the poverty in the country. Nehru believed that if any country wants to developed the in dustrialize rapidly then that country have centralized planned economy. Industrial sector is the main factor to the development of the country's economy.

\footnotetext{
${ }^{5}$ Supra Note 2

${ }^{6}$ https://currentaffairs.gktoday.in/tags/agriculture, last visited at $15 ; 35$, dated on $15 / 07 / 2018$
} 
Industrial sector usually buy the raw materials from the agriculture sector and make the new products. The industrial can classified in two types:- Heavy sector and light sector. Large quantity of the energy was consumed for running the process. The opinion of the economist is that industry creates wealth compared to the service sector. The modern industry in India was introduced in $1818 .^{7}$ When the first cotton mill was established in Kolkata, at that time Kolkata was called Calcutta. The first tanning factory also was established in 1885 at Madras.

The first Jute mill was established in Calcutta in 1852. In nineteenth century many industries are introducing and that are manufacturing of the beverages and the tea, coffee. The Second World War gave the real push to the Indian industry. After the Second World War many metal fabricating mechanical and chemical industries were established as emergence with new technologies. But the disastrous effects of war mainly over the production of goods and over working of the national capital and also effected the distribution of goods in the country.

The foreign rulers had not taken any interest in solving the problems of India. The people which were belonging from the reach family, they never wanted to take any risk in welfare and the development of the country. After the Independence of India and the division of the India and the Pakistan further affected the Indian industries very disastrously, ${ }^{8}$

The Indian industries was hampered so much because some important minerals like Gypsum, Rock salt etc were found in the areas that was the part of the Pakistan after the division of the areas. And also the some important ingredients which are necessary for the heavy chemical industries that are also go to the part of Pakistan. Cotton and Jute industries are also affected by this act as 81 percent of raw materials of jute and the 40 percent of the raw material of cotton was affected because the raw materials were grown in this area which went under Pakistan. Some industries were also affected when the division of the country was completed because most of the skilled labour working in this industry were happened Muslims and they migrated to Pakistan.

\footnotetext{
${ }^{7}$ http://www.economywatch.com/world-industries/industrialsector, last visited at $15: 45$, dated on $15 / 07 / 2018$ ${ }^{8}$ IBID
}

\section{Comparison Between Agriculture Sector And Industrial Sector:}

For the development of the country agriculture and industrial sector both of them are important. Because agri culture sector provided the raw material to the industrial sector for making the goods. There is no doubt without agriculture, country cannot exist and without industry, country cannot develop. Agriculture and the industry both of them are like two wheels of a bicycle, one cannot survive without other. So, it is necessary for a country to have focus both of them agriculture and industrial sector. Here also the difference between us and our ancestors because they were fulfilled their needs only from the agriculture and at that time they have very less scope of comfort. Because at that time lack of the industries, at that time very small cottage industries in our country. this is the main difference between us and our ancestors. They cannot communicate to any one only presses a single button. ${ }^{9}$ This is happened only the help of the industries. But no one can deny of this fact that agriculture is equally important. Industries should be promoted but not by compromising with agriculture, the government of India made the policies to promote both agriculture and industrial sector. In India 46 percent of the land is using for the cultivation and 29 percent of the land is using for the industrial work. This gap of agriculture and industrial sector may be so much high, but more than 70 percent Indian earn their livelihood on agriculture. In India maximum part of the land is not useful for the agriculture because due to the lack of the resources, agriculture is not possible. ${ }^{10}$ This type of land was founded in the western region of the country, which is includes the states like Gujarat and Rajasthan, and also the black soil such as Deccan pleated and central India are less fertile than river plains and this land is only useful for the industries. In India for the increasing the production of the grains and vegetable, modern technologies should be used, which can produce good quality of the goods and at after rate. ${ }^{11}$ During the industrial revolution in $17^{\text {th }}$ century, the production of goods increased due to the use of the modern technology. The industrial revolution was started from the Europeans countries, but effect was felt all over the world, especially on the economy.

\footnotetext{
${ }^{9}$ Supra Note 4

${ }^{10}$ https://www.imarcgroup.com/agriculture-industry-in-india, last visited at 13:58, dated on 15/07/2018

${ }^{11}$ http://www.yourarticlelibrary.com/agriculture/relationshipbetween-agriculture-and-industry/42559, last visited at 14:55, dated on $16 / 07 / 2018$
} 
Food production was also increased after using the modern and scientific method of agriculture. After using the modern technology and scientific method generate the new seeds for high productions of grains and vegetables and the modern method of the irrigation can also benefit to the farmers. The government of India make the new policies to maintain the balance between agriculture and industrial sector.

\section{Best Factors of Economic Development Of Our Country:}

The economic growth of a countries is the increase, when the market value of the goods and services produced by an economy over time. The economic growth of any country can define by an outward shift in its Production possibility curve (PPC). The economic growth of a country is measured by the increase in a country's total output $r$ real Gross Domestic Product (GDP) or Gross National Production (GNP). The Gross Domestic Product (GDP) of a country is the total value of the final foods and service produced in a country over a period of time. If an increase in GDP is increase the country's production. $^{12}$ The economic development of our country is higher than the other developing countries. Economic growth is not same as the Economic development. Developments reduce the people for low standards of living proper employment with suitable shelter. The process is a highly complex phenomenon and is influenced the various factor such as economic, political, social and cultural factors. The some economists believed that the capital is the only requirement of the growth, and the greatest emphasis is laid on capital formation to bring about the economic development. According to the professor Nurkse, "Economic development has much to do with human endowments, social attitudes, political conditions and historical accidents. Capital is a necessary but not a sufficient condition of progress."

Some factors are determining the economic growth and the economic development of the country. The quality and quantity of a natural resources play an important role in the economic development of a country, because natural resources are land, minerals and oil resources, water, forest and the climate, and the climate is the most important part of these natural resources. If all these qualities are available in any

\footnotetext{
${ }^{12}$ http://www.indiastudychannel.com/resources/45013Agriculture-vs-Industry-which-is-more-important.aspx, last visited on $16: 44$, dated on $16 / 07 / 2018$
}

country, then that country produce the large quantity of the gains and the so much output of the goods. Without the natural resources there is no hope of the economic develop meant and for the economic growth not necessary of the natural resources. India is a rich country in natural resources but remained poor and under developed. ${ }^{13}$

This because the resources have not completely utilized for productive purpose, on other hand Japan have a very few natural resources but also the ability to bring them to use and determines the growth and the result is that Japan is the richest countries in the world. Labour and capital both are helpful to increases the economic growth of the country, because both of them are produce goods and services. The labour need machines to do a work in the factories. The factory provided the economic growth to the help of the new technology and the capital make more productive to the labour. ${ }^{14}$

\section{Conclusion: -}

The India is mainly focused on the agriculture sector because in India so much place for the cultivation so the people of India they are mainly focused on this sector and the western area of this country is useful for the industrial sector and the government of India made the new policies for the people of India to always learn about that the industrial and agriculture sector. The India accelerated the growth rate and the higher productivity and improved the living standard to help of the technology. All the world is known about this now India has started the growth and development to the help of the industrial and agriculture sector. India's growth and performance of economics prospects have been increased in past fifteen years. Large numbers of the research are focused on the agriculture growth and some research has done for the industrial growth, many researches find the so much dimension of the research regarding the sect oral growth. An empirical result of the study thus highlights the need for the proper balancing the growth sectors. In his reforms the government of the India mainly focused on the agricultural sector in rural areas. The industrial sector depends upon the agriculture sector because the agriculture sector provided the raw material to the industries. The three sectors considered for the study are agriculture,

\footnotetext{
${ }^{13}$ IBID

${ }^{14}$ http://www.yourarticlelibrary.com/economics/factors-thatdetermine-economic-growth-and-development-of-acountry/38250, last visited on $17: 45$, dated on $16 / 07 / 2018$
} 
industries and services. All the three sectors are linked with the total GDP growth of the nation. The agriculture sector has always been an important contributor to India's GDP. This is not only contributed directly to the growth of GDP but also inspired the industrial sector and service sector growth. The country GDP plays a very important in all round economic and social development of the country.

When India have entered into an atmosphere the competition of this era was increased. The agriculture sector, is continues to be highly monsoon dependent, has been one of the main problems in this sector.

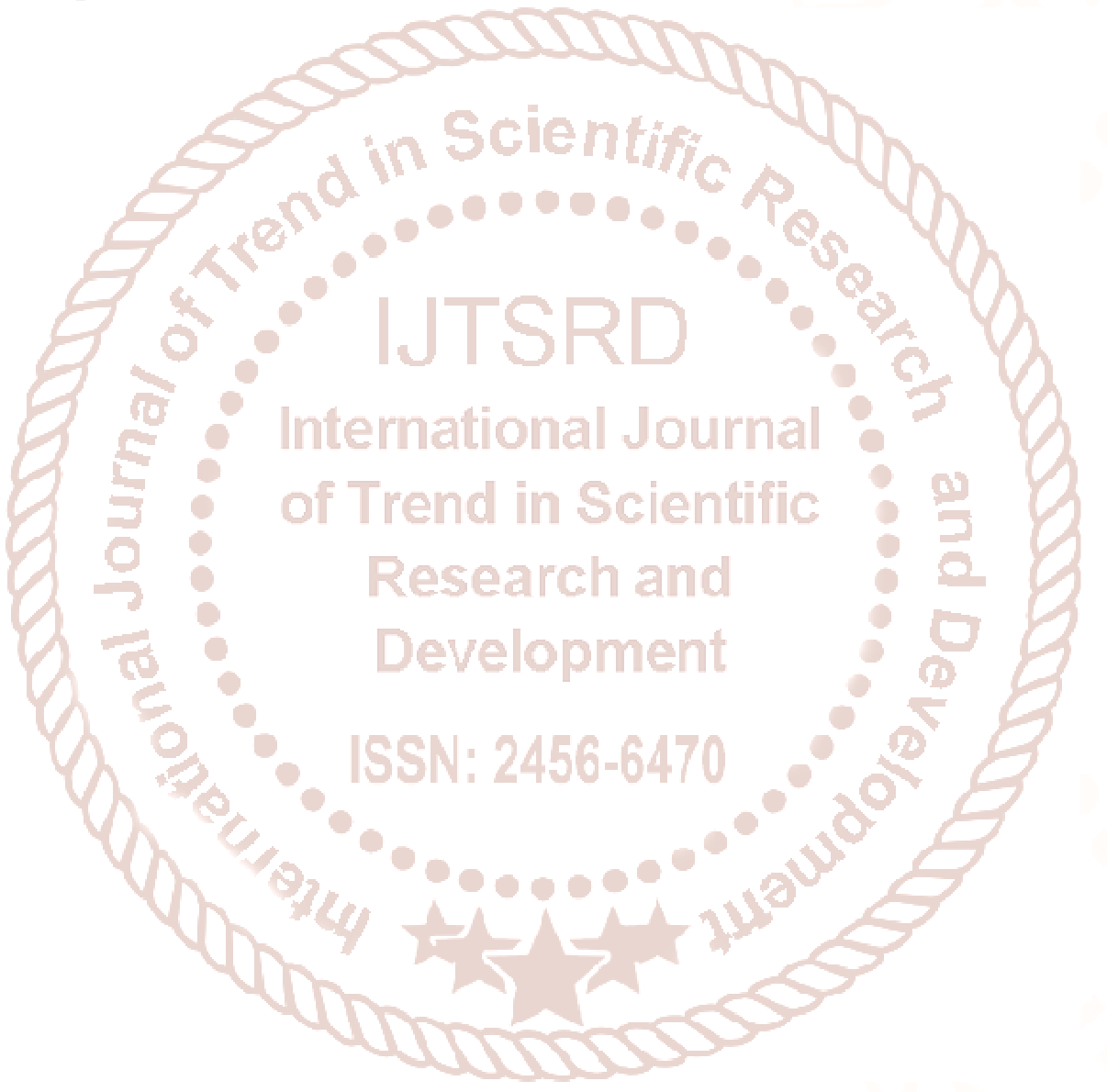

